\title{
Article \\ Cytotoxicity of Fenugreek Sprout and Seed Extracts and Their Bioactive Constituents on MCF-7 Breast Cancer Cells
}

\author{
Kholoud K. Khoja ${ }^{1}$ (D), Melanie-Jayne R. Howes ${ }^{2,3}$, $^{\text {Robert Hider }}{ }^{3}$, Paul A. Sharp ${ }^{1}$, Iain W. Farrell ${ }^{2}$ D \\ and Gladys O. Latunde-Dada ${ }^{1, *(D)}$
}

check for

updates

Citation: Khoja, K.K.; Howes, M.-J.R.; Hider, R.; Sharp, P.A.; Farrell, I.W.; Latunde-Dada, G.O. Cytotoxicity of Fenugreek Sprout and Seed Extracts and Their Bioactive Constituents on MCF-7 Breast Cancer Cells. Nutrients 2022, 14, 784. https://doi.org/ $10.3390 /$ nu14040784

Academic Editor: Salman M. Hyder

Received: 27 December 2021

Accepted: 9 February 2022

Published: 13 February 2022

Publisher's Note: MDPI stays neutral with regard to jurisdictional claims in published maps and institutional affiliations.

Copyright: (C) 2022 by the authors. Licensee MDPI, Basel, Switzerland. This article is an open access article distributed under the terms and conditions of the Creative Commons Attribution (CC BY) license (https:// creativecommons.org/licenses/by/ $4.0 /)$.
1 Department of Nutritional Sciences, School of Life Course Sciences, King's College London, Franklin-Wilkins-Building, 150 Stamford Street, London SE1 9NH, UK; kholoud.khoja@kcl.ac.uk (K.K.K.); paul.a.sharp@kcl.ac.uk (P.A.S.)

2 Royal Botanic Gardens Kew, Richmond TW9 3DS, UK; m.howes@kew.org (M.-J.R.H.); i.farrell@kew.org (I.W.F.)

3 Institute of Pharmaceutical Science, Faculty of Life Sciences and Medicine, King's College London, Franklin-Wilkins-Building, 150 Stamford Street, London SE1 9NH, UK; robert.hider@kcl.ac.uk

* Correspondence: yemisi.latunde-dada@kcl.ac.uk

\begin{abstract}
Trigonella foenum-graecum L. (fenugreek), a member of the legume family (Fabaceae), is a promising source of bioactive phytochemicals, which explains its traditional use for a variety of metabolic disorders including cancer. The current study aimed to evaluate extracts of fenugreek seeds and sprouts, and some of their constituents, to compare their cytotoxic and antiproliferative activities in MCF-7 breast cancer cells. The extracts were chemically characterised using high-resolution accurate mass liquid chromatography-mass spectrometry to reveal the detection of compounds assigned as flavone $\mathrm{C}$-glycosides including those derived from apigenin and luteolin, in addition to isoflavones. Five different flavones or their glycosides (apigenin, vicenin-2, vitexin, luteolin and orientin) and two isoflavones (daidzein and formononetin) were quantified in the fenugreek extracts. The 3-(4,5-dimethylthiazol-2-yl)-2,5-diphenyltetrazolium bromide assay using MCF-7 cells treated with fenugreek methanolic extracts showed dose- and time-dependent effects on cell viability. The MCF-7 cancer cells treated with the fenugreek methanolic extracts also displayed increased relative mitochondrial DNA damage as well as suppressed metastasis and proliferation. This study demonstrates the potential anti-cancer effects of fenugreek seeds and sprouts and reveals fenugreek sprouts as an untapped resource for bioactive compounds.
\end{abstract}

Keywords: fenugreek; cytotoxicity; MCF-7; iron; cancer

\section{Introduction}

Trigonella foenum-graecum L., commonly known as fenugreek, is an annual legume belonging to the Fabaceae family and is cultivated as a cash crop for its seeds. This herb is native to Afghanistan, Iran, Iraq, and Pakistan and has been introduced to a range of other countries [1]. The fenugreek seed extract is used as a flavouring ingredient to produce alternative syrups with maple or hydrolysed vegetable protein flavour [2]. It is also used as a tobacco flavouring, a perfume base, and a source of steroidal sapogenin compounds in the pharmaceutical industry [3]. Fenugreek leaves are commonly consumed as a vegetable and are a flavouring ingredient in Indian dishes, in which the plant is known by the common name 'methi' $[2,4]$.

Fenugreek is of interest for use in cancer therapy because it has antioxidant and immunostimulatory activity [5]. Both its seeds and leaves contain phytochemicals including flavonoids, alkaloids, and tannins [4]. The putative therapeutic benefits of fenugreek are considered to be due to the phytoestrogens, saponins, and flavonoids present in the plant's seeds and leaves [6]. Different types of flavonoids and their glycosides occur in fenugreek seed extracts including those derived from the flavones apigenin and luteolin, 
and the flavonol kaempferol [7]. In a previous study, fenugreek seed extracts fed to rats at a dose of $200 \mathrm{mg} / \mathrm{kg}$ body weight significantly inhibited 7,12-dimethylbenz(a)anthracene (DMBA)-induced mammary hyperplasia and decreased its incidence in these test animals [8], indicating that fenugreek seed extracts have potential anti-breast cancer benefits. Even though fenugreek leaves have long been used as a vegetable due to their nutritional benefits $[2,4]$, there is limited data on their bioactive constituents. However, some studies suggest that germinated fenugreek seeds (i.e., sprouts) have a higher antioxidant content than boiled non-germinated fenugreek seeds [9]. The sprouting of fenugreek seeds is thought to increase the release, or the bioavailability, of bound antioxidants and other bioactive compounds [9]. Due to the promising but previously understudied effects of fenugreek sprouts, this study aimed to determine the bioactive compounds in fenugreek sprouts compared to seeds, and evaluate their effect on the proliferation of cultured breast cancer cells (MCF-7). Furthermore, the mechanism of apoptotic cell death induced by fenugreek in MCF-7 cells was also investigated to provide new insights into the potential for fenugreek sprouts to have a role against cancer.

\section{Materials and Methods}

\subsection{Reagents and Chemicals}

Unless otherwise stated, all the reagents and chemicals used in this study were purchased from Sigma-Aldrich Ltd. (Dorset, UK). Solutions of enzymes were all prepared freshly just before use.

\subsection{Extraction}

Organic fenugreek sprouts and seeds were obtained from Planet Organic (UK). The sprouts were air-dried at room temperature, and both the seeds and sprouts were then ground separately in a classic Moulinex AR1043 grinder prior to sequential Soxhlet extraction, described as follows.

A total of $100 \mathrm{~g}$ of milled powder from the dried sprouts or seeds was extracted with $200 \mathrm{~mL}$ methanol [MeOH], (Sigma 34860) $n$-hexane (Sigma 139386), or chloroform (Sigma $650498)$ for $24 \mathrm{~h}$ at $40 \pm 2{ }^{\circ} \mathrm{C}$. The organic solvent was 10 times $(v / w)$ the sample weight, and extraction via Soxhlet continued until the solvent became colourless. The solvents were used in the following order: (A) $\mathrm{MeOH} / n$-hexane; extract residue then extracted with chloroform; (B) chloroform/n-hexane; extract residue then extracted with $\mathrm{MeOH}$; (C) chloroform only. The extracts residues were stored at $-20^{\circ} \mathrm{C}$ prior to analysis.

\subsection{High-Resolution Accurate Mass Liquid Chromatography-Mass Spectrometry Analysis of Extracts}

The fenugreek extracts were subjected to high-resolution accurate mass liquid chromatography-photodiode array-mass spectrometry (HRAM LC-PDA-MS/MS) analysis. The extracts were prepared at $10 \mathrm{mg} / \mathrm{mL}$ in $100 \% \mathrm{MeOH}$ and then sonicated for $20 \mathrm{~min}$ before LC-MS analysis. The analyses were performed on a Thermo Scientific system consisting of an 'Accela' U-HPLC unit with a photodiode array detector and an 'LTQ Orbitrap XL' mass spectrometer fitted with an electrospray source (Thermo Scientific, Waltham, MA, USA). Chromatography was performed with $5 \mu \mathrm{L}$ sample injections (per extract) onto a $150 \mathrm{~mm} \times 3 \mathrm{~mm}, 3 \mu \mathrm{m}$ Luna C-18 column (Phenomenex, Torrance, CA, USA) using the following $400 \mu \mathrm{L} / \mathrm{min}$ mobile phase gradient of $\mathrm{CH}_{3} \mathrm{OH} / \mathrm{H}_{2} \mathrm{O} / \mathrm{CH}_{3} \mathrm{CN}+1 \% \mathrm{HCOOH}$ : 0:90:10 (0 $\mathrm{min})$, 90:0:10 (60 $\mathrm{min}), 90: 0: 10$ (65 $\mathrm{min})$, 0:90:10 (67 $\mathrm{min})$, and 0:90:10 (70 $\mathrm{min})$. The electrospray source was set to record high-resolution (30 k resolution) mass spectra [MS1] $(m / z$ 125-2000) in positive mode using the orbitrap and data-dependent MS2 and MS3 spectra in both modes using the linear ion trap. Detected compounds were assigned by comparison of the accurate mass data and interpretation of the MS2, MS3, and UV spectra and the published compound assignment system [10]. 


\subsection{Quantitative Analysis of Compounds Detected in Fenugreek Extracts}

The fenugreek sprout and seed extracts were analysed at $50 \mathrm{mg} / \mathrm{mL}$ in duplicate using a Thermo Fisher Velos Pro LC-PDA_MS. Samples $(5 \mu \mathrm{L})$ were injected directly onto a Phenomenex Luna C-18 (2) column ( $150 \mathrm{~mm}, 3 \mathrm{~mm}$ i.d., $3 \mu \mathrm{m}$ particle size) at $400 \mu \mathrm{L} / \mathrm{min}$ and eluted using a linear gradient of 90:0:10 $(t=0 \mathrm{~min})$ to 0:90:10 $(\mathrm{t}=20-25 \mathrm{~min})$, returning to $90: 0: 10(\mathrm{t}=27-30 \mathrm{~min})$. The solvents were water, $\mathrm{MeOH}$, and $1 \%$ formic acid in acetonitrile, respectively. The column was maintained at $30^{\circ} \mathrm{C}$. Compounds were detected with a Thermo Fisher Velos Pro Dual-Pressure Linear Ion Trap Mass Spectrometer. Samples were scanned using the ITMS from $\mathrm{m} / \mathrm{z} 200$ to 600 , and the UV peak areas were quantified against the calibration curves of the reference standards (apigenin, vicenin-2, vitexin, luteolin, orientin, formononetin, and daidzein; Sigma), which were analysed in duplicate over a concentration range of $0.32-2000 \mu \mathrm{g} / \mathrm{mL}$ using the same LC-PDA-MS method.

\subsection{Cell Culture}

The breast cancer cell line MCF-7 cells on passages 35-40 and non-tumorigenic epithelial cell line MCF-10A cells on passages 4-9 were obtained from the American Type Culture Collection [ATCC].

The cells were sub-cultured in a $75-\mathrm{cm}^{2}$ flask at $\sim 70 \%$ confluency. The growth medium contained Dulbecco's modified Eagle medium [DMEM] and high glucose with glutamine (Sigma D5796), and was supplemented with 10\% foetal bovine serum [FBS] (Sigma 2442) and 1\% penicillin-streptomycin (Sigma 9644). The MCF-10A cells were subcultured in DMEM (Sigma 5648) and Ham's F-12 base (Sigma D9785) supplemented with $20 \mathrm{ng} / \mathrm{mL}$ epidermal growth factor (Sigma E9644), $100 \mathrm{ng} / \mathrm{mL}$ cholera toxin (Sigma C8052), $0.01 \mathrm{mg} / \mathrm{mL}$ human insulin (Sigma I2643), $500 \mathrm{ng} / \mathrm{mL}$ hydrocortisone, and $5 \%$ horse serum (Gibco 26050-088).

Both cell types were incubated at $37^{\circ} \mathrm{C}$, with $95 \%$ humidity and $5 \%$ carbon dioxide. The growth medium was changed every two days. The cells were harvested after three washes with phosphate-buffered saline [PBS] (Sigma P5493) and incubated with 2-5 mL Trypsin-ethylenediaminetetraacetic acid [EDTA] (Sigma T3924) until the cells detached (5-10 min). Culture medium ( $5 \mathrm{~mL}$ ) was added, and the cells were collected and centrifuged at $107 \times g$ for five minutes.

\subsection{Cell Viability Studies}

Cells were seeded at a density of $1 \times 10^{4}$ cells $/ \mathrm{cm}^{2}$ in 96-well plates. The medium was discarded, and the cells were washed three times with sterile phosphate-buffered saline [PBS] and then incubated and treated at different time points according to the experimental plan. The cells were treated with different concentrations of the test compounds (fenugreek sprouts, fenugreek seeds) and incubated for a variable time. Following this, $100 \mu \mathrm{L}$ of fresh modified Eagle's medium [DME] (no phenol red Thermofisher 210633029) along with $10 \mu \mathrm{L}$ of dimethylthiazol-2-yl)-2,5-diphenyltetrazolium bromide [MTT] (Sigma M2003) sterile solution ( $5 \mathrm{mg} / \mathrm{mL}$ MTT in PBS) were added to each well. After incubating for $3 \mathrm{~h}$ in the dark at $37^{\circ} \mathrm{C}, 100 \mu \mathrm{L}$ of a solubilisation buffer in dimethyl sulfoxide [DMSO] (Sigma D4540) was added and incubated for $15 \mathrm{~min}$ at room temperature. To determine the MTT reaction in the cells, optical density was read in a microplate reader (Bio-Tek ELx800) at $490 \mathrm{~nm}$. Cell viability was expressed as a percentage of the controls. The calculation was conducted as outlined below:

$$
50 \% \text { inhibition }=\mathrm{IC}_{50}=100 /\left(1+10^{\wedge}\left((\log \mathrm{IC} 50-\mathrm{X})^{*} \text { HillSlope }\right)\right) .
$$

\subsection{Proliferation Assay}

This assay quantifies cell proliferation based on the incorporation of the pyrimidine analogue 5-bromo- 2 -deoxyuridine [BrdU] into cellular DNA (during DNA replication) in exchange for thymidine. The integrated BrdU is detected by the peroxidase-conjugated antiBrdU antibody, followed by a colourimetric reaction including tetramethylbenzidine [TMB]. 
Herein, the assay was used according to the manufacturer's instructions. The Cell Proliferation enzyme-linked immunosorbent assay [ELISA], BrdU colourimetric (Roche, 11647229001) Assay Kit was used according to the manufacturer's instructions. The treated cells were seeded at $10^{4}$ in a white-rimmed 96-well plate (Corning 353377). The BrdU was added to a final concentration of $10 \mu \mathrm{M}$ at $10 \mu \mathrm{L} \mathrm{BrdU} / 100 \mu \mathrm{L}$ sterile DME per well for one hour at $37^{\circ} \mathrm{C}$. After removing the labelling medium, the plates were incubated for $30 \mathrm{~min}$ at room temperature to fix the cells, and the DNA was denatured after adding $200 \mathrm{~mL} /$ well FixDenat. The cells were incubated with $50 \mu \mathrm{L} /$ well of peroxidase-conjugated anti-BrdU antibody for $90 \mathrm{~min}$ at room temperature after the removal of the FixDenat solution. Immune complexes were detected after washing with PBS once using $100 \mu \mathrm{L} /$ well TMB substrate reaction until colour development. Luminescence was measured after an incubation of 10-15 min at $450 \mathrm{~nm}$ using a Monolight 3096 microplate luminometer (BD Bioscience). The MCF-7 cells were treated overnight with the $\mathrm{IC}_{50}$ of the finished sprouts and seeds in methanol extracts.

\subsection{Real-Time Quantitative PCR}

Total genomic DNA was extracted using Qiagen (Germany) according to the manufacturer's instructions. DNA samples were sonicated as described [11], and the concentration was determined using the NanoDrop and adjusted to $10 \mathrm{ng} / \mu \mathrm{L}$. The Applied BioSystem Fast Real-Time PCR System-7900HT Kit was used to carry out the qRT-PCR of DNA of the samples with specific forward and reverse primers and probes (Roche, Germany) designed to target mitochondrial DNA using the human mitochondrial genome [hMito] gene; the level was normalised to the human Beta-2 microglobulin [hB2M] nuclear gene. Following this, the samples were seeded into 96- $\times$ 4-well PCR plates using a robot (BioMex FX-Beckman Coulter). The results of relative content were expressed as $\Delta \mathrm{Ct}=\mathrm{Ct}$ (gene of interest) $-\mathrm{Ct}$ (housekeeping gene) and $\Delta \Delta \mathrm{Ct}=\Delta \mathrm{Ct}$ (treated) $-\Delta \mathrm{Ct}$ (control).

\subsection{Statistical Analysis}

Experiments were performed in 3-6 replicates, and data are shown as mean \pm standard error of the means (SEM). The comparisons were analysed using one-way or two-way analysis of variance [ANOVA] followed by Tukey's post hoc test where appropriate using the GraphPad Prism software. The significance level was at $p \leq 0.05$.

\section{Results}

\subsection{Fenugreek Sprout and Seed Extractions}

The extract yields from the dry ground fenugreek sprouts and seeds after Soxhlet extraction are shown in Table 1 with different yields being observed between seeds and sprouts and the extraction solvent.

Table 1. Extraction yields from fenugreek sprouts and seeds using different solvents.

\begin{tabular}{cccc}
\hline Sample & Organic Solvent & Sample (g) & Yield (\%) \\
\hline & 1st Methanol Extraction & 22.83 \\
\cline { 2 - 3 } & 2nd Chloroform Extraction & 100 & 1.88 \\
\cline { 2 - 4 } & 3rd Hexane Extraction & \multirow{2}{*}{0.09} \\
\cline { 2 - 4 } & 1st Hexane Extraction & 100 & 6.14 \\
\cline { 2 - 4 } & 2nd Chloroform Extraction & 1.24 \\
\cline { 2 - 4 } & 3rd Methanol Extraction & 100 & 12.51 \\
\hline
\end{tabular}


Table 1. Cont.

\begin{tabular}{|c|c|c|c|}
\hline Sample & Organic Solvent & Sample (g) & Yield (\%) \\
\hline \multirow{7}{*}{ Seeds } & 1st Methanol Extraction & \multirow{3}{*}{100} & 17.19 \\
\hline & 2nd Chloroform Extraction & & 1.25 \\
\hline & 3rd Hexane Extraction & & 0.00 \\
\hline & 1st Hexane Extraction & \multirow{3}{*}{100} & 5.93 \\
\hline & 2nd Chloroform Extraction & & 1.45 \\
\hline & 3rd Methanol Extraction & & 10.95 \\
\hline & Chloroform Extraction & 100 & 3.08 \\
\hline
\end{tabular}

\subsection{LC-MS Analysis of Fenugreek Seed and Sprout Extracts}

The assigned compounds detected in the fenugreek extracts are shown in Supplementary Table S1. Numerous apigenin C-glycosides including compounds assigned as vitexin and isovitexin were the main compound class detected in the first FPME, third FPME, first FSME, and third FSME. Detected also in the first and third FPMEs and FSMEs were compounds assigned as luteolin C-glycosides.

Other compound classes detected included those assigned as isoflavones: $3^{\prime}, 5,7-$ trihydroxy-5'-methoxy-isoflavone in the first and third FPMEs and third FPHE, formononetin hexoside in the second FPCE (after hexane, before methanol) and daidzein or isomer in the first and third FPMEs. A range of compounds assigned as steroidal saponins was also detected primarily in the methanolic fenugreek extracts.

\subsection{Content of Specific Flavonoids in the Fenugreek Extracts}

Certain flavonoids that were detected in the fenugreek extracts or the aglycones of the detected flavonoids (Supplementary Table S1) were sourced as reference standards for quantification in the fenugreek methanol extracts and for testing in the MTT assay on MCF-7 cells (Table 2).

The quantitative analyses revealed that certain flavonoids (ascertained as bioactive; Table 1), except for formononetin, occurred at higher concentrations in the third FPME compared to the first. Moreover, orientin and daidzein occurred at higher concentrations in the first FSME, while vicenin-2 and vitexin occurred at higher concentrations in the third. The $\mathrm{IC}_{50}$ values for apigenin $(39.91 \mu \mathrm{M})$, luteolin $(35 \mu \mathrm{M})$, and formononetin $(50.13 \mu \mathrm{M})$ indicated these flavonoids could reduce the cell viability of MCF-7 cells (Table 2), indicating these compounds could have contributed to the activity of the extracts in which they were detected. 
Table 2. Flavonoids quantified in the fenugreek methanol extracts and their $\mathrm{IC}_{50}$ values when tested individually on MCF-7 cells

\begin{tabular}{|c|c|c|c|c|c|c|c|c|c|}
\hline $\begin{array}{l}\text { Plant Part and Extract } \\
\text { (Assigned Compound) }\end{array}$ & & Synonym & $\begin{array}{l}\text { Molecular } \\
\text { Weight }\end{array}$ & $\begin{array}{l}\text { Molecular } \\
\text { Formula }\end{array}$ & $\mathrm{IC}_{50} \mu \mathrm{M}$ & $\begin{array}{l}\text { 1st FPME } \\
\mu \mathrm{g} / 50 \mathrm{mg}\end{array}$ & $\begin{array}{l}\text { 3rd FPME } \\
\mu \mathrm{g} / 50 \mathrm{mg}\end{array}$ & $\begin{array}{l}\text { 1st FSME } \\
\mu \mathrm{g} / 50 \mathrm{mg}\end{array}$ & $\begin{array}{l}\text { 3rd FSME } \\
\mu \mathrm{g} / 50 \mathrm{mg}\end{array}$ \\
\hline \multirow{5}{*}{ Flavones } & Apigenin & $4^{\prime}, 5,7$-Trihydroxyflavone & 270.24 & $\mathrm{C}_{15} \mathrm{H}_{10} \mathrm{O}_{5}$ & $39.91 \pm 1.72$ & $\begin{array}{c}6.3 \\
{[0.023]}\end{array}$ & $\begin{array}{c}9.84 \\
{[0.036]}\end{array}$ & $\begin{array}{c}0.78 \\
{[0.002]}\end{array}$ & $\begin{array}{c}0.62 \\
{[0.002]}\end{array}$ \\
\hline & Vicenin-2 & $\begin{array}{c}\text { Apigenin } \\
\text { 6,8-C-di-glucoside }\end{array}$ & 594.52 & $\mathrm{C}_{27} \mathrm{H}_{30} \mathrm{O}_{15}$ & $199.1 \pm 1.48$ & $\begin{array}{c}10.0 \\
{[0.017]}\end{array}$ & $\begin{array}{c}12.0 \\
{[0.021]}\end{array}$ & $\begin{array}{c}30.0 \\
{[0.050]}\end{array}$ & $\begin{array}{c}279.0 \\
{[0.470]}\end{array}$ \\
\hline & Vitexin & Apigenin 8 -C-glucoside & 432.38 & $\mathrm{C}_{21} \mathrm{H}_{20} \mathrm{O}_{10}$ & $247.4 \pm 1.61$ & $\begin{array}{c}8.5 \\
{[0.020]}\end{array}$ & $\begin{array}{c}11.5 \\
{[0.027]}\end{array}$ & $\begin{array}{c}57.8114 .6 \\
{[0.266]}\end{array}$ & $\begin{array}{l}121.4 \\
{[0.281}\end{array}$ \\
\hline & Luteolin & $\begin{array}{c}3^{\prime}, 4^{\prime}, 5,7- \\
\text { Tetrahydroxyflavone }\end{array}$ & 286.24 & $\mathrm{C}_{15} \mathrm{H}_{10} \mathrm{O}_{6}$ & $35 \pm 1.95$ & $\begin{array}{c}13.0 \\
{[0.045]}\end{array}$ & $\begin{array}{c}14.4 \\
{[0.050]}\end{array}$ & $\begin{array}{c}32.6 \\
{[0.114]}\end{array}$ & $\begin{array}{c}28.6 \\
{[0.100]}\end{array}$ \\
\hline & Orientin & Luteolin 8 - $C$ - glucoside & 448.38 & $\mathrm{C}_{21} \mathrm{H}_{20} \mathrm{O}_{11}$ & $277 \pm 2.95$ & $\begin{array}{c}63.0 \\
{[0.141]}\end{array}$ & $\begin{array}{c}73.0 \\
{[0.163]}\end{array}$ & $\begin{array}{l}5212.0 \\
{[11.632]}\end{array}$ & $\begin{array}{l}11538.0 \\
{[25.755]}\end{array}$ \\
\hline \multirow{2}{*}{ Isoflavones } & Daidzein & $\begin{array}{c}4^{\prime}, 7- \\
\text { Dihydroxyisoflavone }\end{array}$ & 254.24 & $\mathrm{C}_{15} \mathrm{H}_{10} \mathrm{O}_{4}$ & $152.2 \pm 1.94$ & $\begin{array}{c}3.8 \\
{[0.015]}\end{array}$ & $\begin{array}{c}3.6 \\
{[0.014]}\end{array}$ & $\begin{array}{c}127.8 \\
{[0.504]}\end{array}$ & $\begin{array}{c}12.5 \\
{[0.049]}\end{array}$ \\
\hline & Formononetin & Daidzein $4^{\prime}$-methyl ether & 268.26 & $\mathrm{C}_{16} \mathrm{H}_{12} \mathrm{O}_{4}$ & $50.13 \pm 2.52$ & $\begin{array}{c}34.0 \\
{[0.127]}\end{array}$ & $\begin{array}{c}16.1 \\
{[0.060]}\end{array}$ & $\begin{array}{c}5.2 \\
{[0.020]}\end{array}$ & $\begin{array}{c}2.9 \\
{[0.011]}\end{array}$ \\
\hline
\end{tabular}

Flavonoid content of fenugreek sprout and seed extracts ( $\mu \mathrm{g} / 50 \mathrm{mg}$ extract), [mmol/50 mg extract]. 1st Fenugreek Sprouts Methanol Extraction [1st FPME], 3rd Fenugreek Sprouts Methanol Extraction [3rd FPME], 1st Fenugreek Seeds Methanol Extraction [1st FSME], 3rd Fenugreek Seeds Methanol Extraction [3rd FSME]. The values in parentheses are in the 95\% range. The IC 50 values for the individual flavonoids on MCF-7 cell death at $24 \mathrm{~h}$. The values are presented as means $n=3 \pm$ SEM. 


\subsection{Cell Viability}

Figure 1 presents the viability of the MCF-7 cells treated with the fenugreek methanol extracts; data are presented as a percentage and normalised against the untreated control. Following $24 \mathrm{~h}$ of incubation, all fenugreek methanol extracts reduced the cellular viability of the cultured breast cancer MCF-7 cells tested over the concentration range $(0-6000 \mu \mathrm{g} / \mathrm{mL}$; Figure 1). The first and third methanol extracts prepared from fenugreek seeds and sprouts produced $\mathrm{IC}_{50}$ values of 5605 and $812 \mu \mathrm{g} / \mathrm{mL}$ and 1400 and $526 \mu \mathrm{g} / \mathrm{mL}$, respectively. The cell viability results demonstrated that both $\mathrm{MeOH}$ extracts from the fenugreek sprouts were more potent than those from the seeds. For both seeds and sprouts, the third $\mathrm{MeOH}$ extracts were more potent than the first. Thus, the third $\mathrm{MeOH}$ fenugreek extracts were selected for further study.

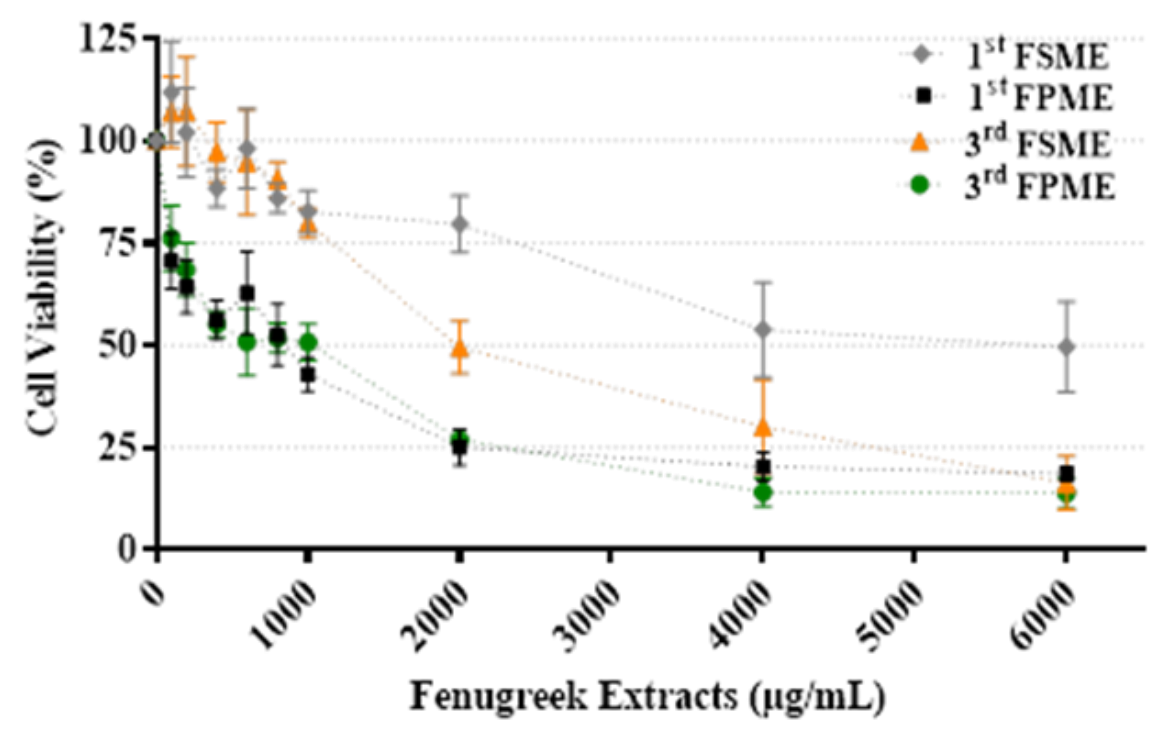

Figure 1. Cell viability of MCF-7 cells treated with various concentrations of fenugreek sprout and seed methanol extracts $(0-6000 \mu \mathrm{g} / \mathrm{mL})$ for $24 \mathrm{~h}$. 1st Fenugreek Sprouts Methanol Extraction [1st FPME], 3rd Fenugreek Sprouts Methanol Extraction [3rd FPME], 1st Fenugreek Seeds Methanol Extraction [1st FSME], 3rd Fenugreek Seeds Methanol Extraction [3rd FSME]. The values are presented as means $n=6 \pm$ SEM.

The cytotoxic effect of the fenugreek methanol extracts on the MCF-7 cells was evaluated using an MTT assay. As shown in Figure 2, the cell viability percentages of the MCF-7 cells were $47.7,47.3,33.52 \%$ and $47.7,47.3,33.5 \%$ with the first, and $53.2,25.4,13.8 \%$ and $57.71,34.22,28.27 \%$ with the third methanol seed and sprout extracts, respectively, which caused a time-dependent inhibition of the MCF-7 cell growth (over 24, 48, and $72 \mathrm{~h}$ ). At $24 \mathrm{~h}$, the $\mathrm{IC}_{50}$ value was significantly higher than at 48 and $72 \mathrm{~h}$ of incubation time, except for the cells treated with the first FSME. 


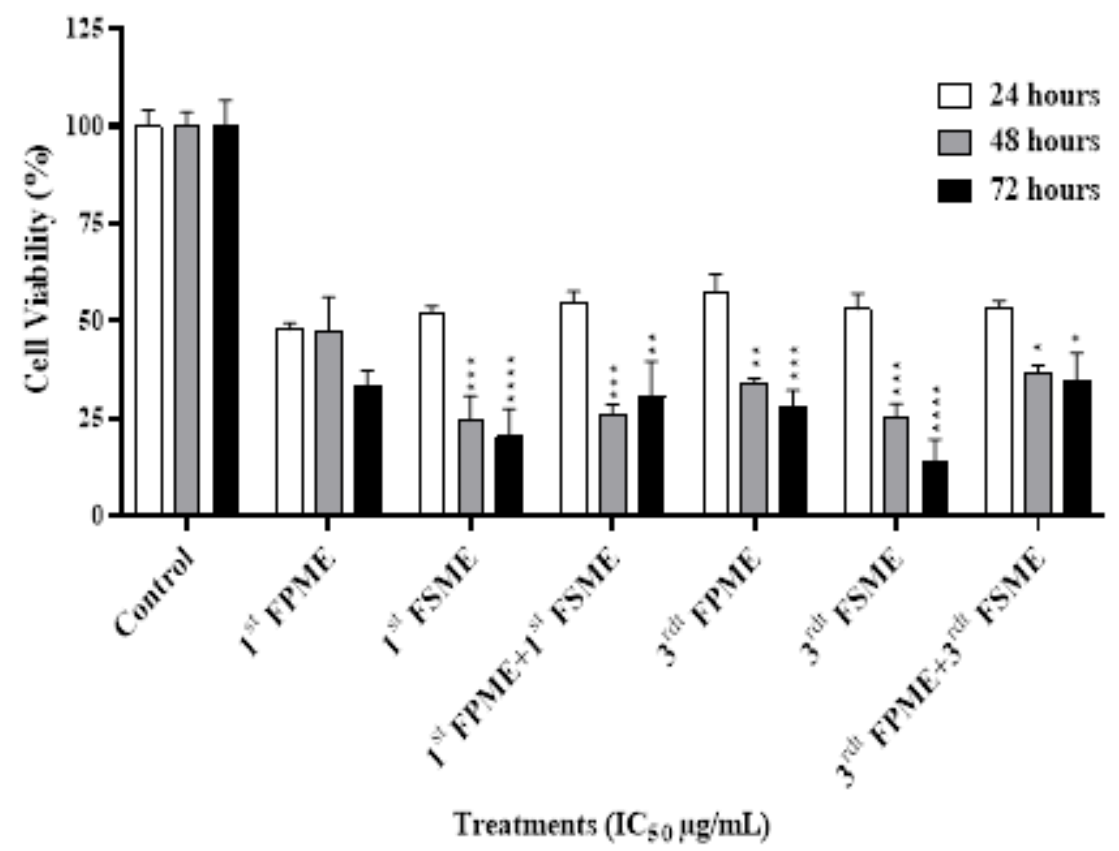

Figure 2. Fenugreek-inhibited cell growth in MCF-7 human breast cancer cells. The viability of the cells was analysed using cell MTT assays. 1st Fenugreek Sprouts Methanol Extraction [1st FPME], 3rd Fenugreek Sprouts Methanol Extraction [3rd FPME], 1st Fenugreek Seeds Methanol Extraction [1st FSME], 3rd Fenugreek Seeds Methanol Extraction [3rd FSME]. The $\mathrm{IC}_{50}$ treatments of the first FSME at $5605 \mu \mathrm{g} / \mathrm{mL}$, first FPME at $812 \mu \mathrm{g} / \mathrm{mL}$, third FSME at $1400 \mu \mathrm{g} / \mathrm{mL}$, and third FPME at $526 \mu \mathrm{g} / \mathrm{mL}$ for 24,48 , and $72 \mathrm{~h}$ decreased the viability of the MCF-7 cells in a time-dependent manner. The values are presented as means $n=6 \pm$ SEM. The data were analysed using a one-way ANOVA test. Different asterisks indicate significant differences between data in the same group ${ }^{*} p \leq 0.05$, ${ }^{* *} p \leq 0.01,{ }^{* * *} p \leq 0.001$, and $\left.{ }^{* * * *} p \leq 0.0001\right)$.

\subsection{Cell Proliferation}

A proliferation assay was performed on the MCF-7 cells following the various treatments. The fenugreek methanol extracts inhibited cell proliferation in a time-dependent manner (Figure 3). The $\mathrm{IC}_{50}$ values of the first and third methanol extracts from the seeds and sprouts at 5605 and $812 \mu \mathrm{g} / \mathrm{mL}$ and 1400 and $526 \mu \mathrm{g} / \mathrm{mL}$, respectively, decreased the proliferation of the MCF-7 cells significantly $(p \leq 0.0001)$ after 48 and $72 \mathrm{~h}$. However, the first FSME treatment did not affect the cells' DNA proliferation over the concentration range tested (Figure 3). 


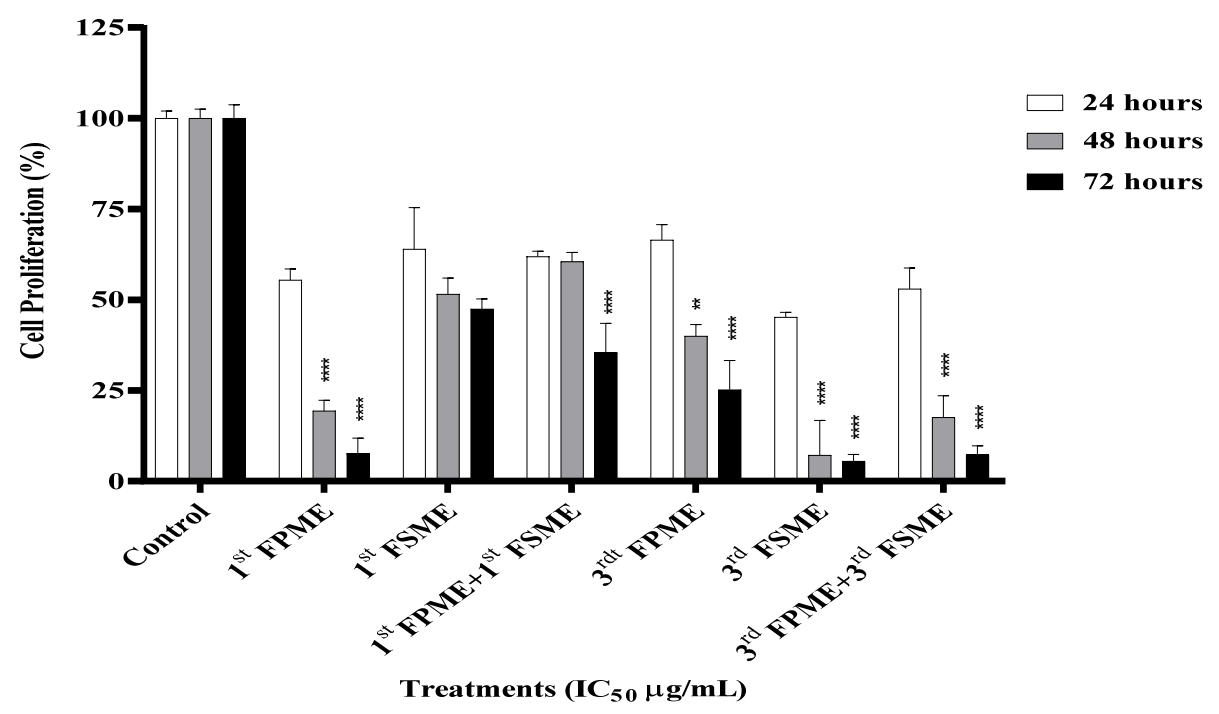

Figure 3. Fenugreek-inhibited cell proliferation of MCF-7 human breast cancer cells. The proliferation of cells was analysed using a cell proliferation assay. 1st Fenugreek Sprouts Methanol Extraction [1st FPME], 3rd Fenugreek Sprouts Methanol Extraction [3rd FPME], 1st Fenugreek Seeds Methanol Extraction [1st FSME], 3rd Fenugreek Seeds Methanol Extraction [3rd FSME]. The $\mathrm{IC}_{50}$ treatment of the 3rd FSME at $5605 \mu \mathrm{g} / \mathrm{mL}$, 1st FPME at $812 \mu \mathrm{g} / \mathrm{mL}$, 3rd FSME at $1400 \mu \mathrm{g} / \mathrm{mL}$, and 3rd FPME at $526 \mu \mathrm{g} / \mathrm{mL}$ for 24,48 , and $72 \mathrm{~h}$ decreased the proliferation of the MCF-7 cells in a time-dependent manner. The values are presented as means $n=6 \pm$ SEM. The data were analysed using a one-way ANOVA test. Different asterisks indicate significant differences between data in the same group $\left({ }^{* *} p \leq 0.01\right.$, and $\left.{ }^{* * * *} p \leq 0.0001\right)$.

\subsection{Mitochondrial DNA (mtDNA) Damage}

The third fenugreek seeds sprout methanol extracts significantly promoted cell mtDNA damage $(p \leq 0.05)$, while the sprout extract was more potent than the seed extract overall. The increased relative mtDNA damage inhibited the standard characteristics of metastatic MCF-7 cell growth and proliferation (Figure 4), and this could have contributed to the high cell death of the MCF-7 cells that were treated with the fenugreek extracts.

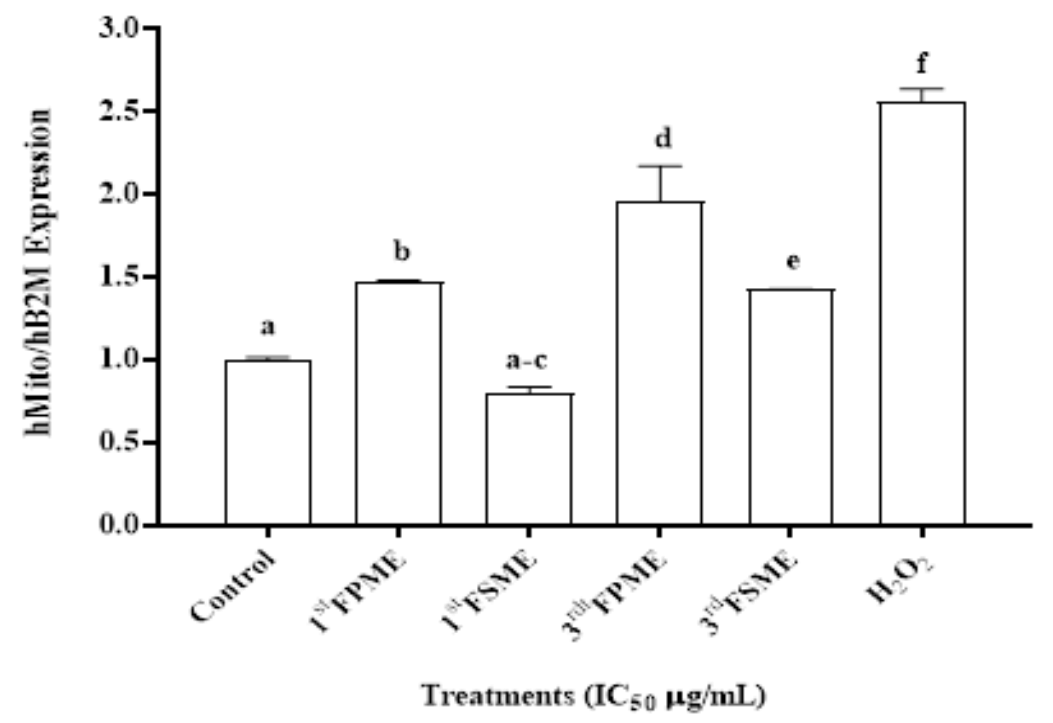

Figure 4. The mtDNA relative content in the MCF-7 cells. Amplified by RT-PCR and normalised to the human Beta-2 microglobulin $[\mathrm{hB} 2 \mathrm{M}]$ nuclear gene after $\mathrm{IC}_{50}$ treatment of the 3rd FSME at $5605 \mu \mathrm{g} / \mathrm{mL}, 1 \mathrm{st}$ FPME at $812 \mu \mathrm{g} / \mathrm{mL}, 3 \mathrm{rd} \mathrm{FSME}$ at $1400 \mu \mathrm{g} / \mathrm{mL}$, and 3rd FPME at $526 \mu \mathrm{g} / \mathrm{mL}$ in the 
MCF-7 cells for $24 \mathrm{~h} ; \mathrm{H}_{2} \mathrm{O}_{2}$ was used as a positive control. 1st Fenugreek Sprouts Methanol Extraction [1st FPME], 3rd Fenugreek Sprouts Methanol Extraction [3rd FPME], 1st Fenugreek Seeds Methanol Extraction [1st FSME], 3rd Fenugreek Seeds Methanol Extraction [3rd FSME], hydrogen peroxide $\left[\mathrm{H}_{2} \mathrm{O}_{2}\right]$ (Sigma H1009). The values are presented as means $n=4 \pm$ SEM. The data were analysed using a two-way ANOVA test. The different letters on top of the bars indicate significant differences $(p \leq 0.05)$ between the data.

\section{Discussion}

Of the three extraction solvents used ( $n$-hexane, methanol, and chloroform), methanol was the most efficient at obtaining the highest extraction yields from the fenugreek sprouts and seeds. This was also demonstrated in a recent study in which bioactive phytochemicals were extracted from fenugreek seeds using a hydromethanolic solution (50/50, v/v) [7]. LC-MS analysis revealed that flavonoids and their glycosides, particularly apigenin $C$ glycosides, were the main compounds detected in the fenugreek extracts. Luteolin $C$ glycosides were also detected but were less abundant. This was consistent with a recent study [12] in which apigenin and luteolin adducts were the most abundant flavonoid glycosides in germinated fenugreek seed extracts. In an earlier study [7], the major constituents included non-acylated flavonoid glycosides (48\%), acylated flavonoid glycosides (46\%), and phenolic acids (6\%), and the major flavonoid constituents included apigenin $(61 \%)$, luteolin (21\%), and kaempferol (11\%). These results were consistent with those of the current study, in which flavone derivatives were predominant in the fenugreek seed extracts.

Herein, five different flavones or their glycosides (apigenin, vicenin-2, vitexin, luteolin and orientin) and two isoflavones (daidzein and formononetin) were quantified in the fenugreek extracts. Apigenin glycosides including vitexin and vicenin-1 and -2 were previously quantified in fenugreek seeds [13]. Among the flavones or their glycosides detected, apigenin was more abundant in the FPMEs than in the FSMEs, while the yields of vicenin-2, luteolin, orientin, and vitexin were more abundant in the FSMEs than in the FPMEs. Among the isoflavones detected, daidzein was more abundant in the seeds, while formononetin was more abundant in the sprouts. Thus, consistent with the literature $[13,14]$, the findings from the current study indicated that flavones are primarily present in fenugreek seeds, while isoflavones are more abundant in fenugreek sprouts.

Herein, the FPMEs and FSMEs reduced cell viability in a dose- and time-dependent manner, consistent with two previous studies on seeds [15,16], and showed these effects for the first time with fenugreek sprout extracts. Sebastian and Thampan [16] reported that an ethanolic extract of fenugreek seeds at a concentration of $50 \mu \mathrm{g} / \mathrm{mL}$ resulted in a 70\% decrease in MCF-7 cell viability during a 72-h culture [16]. Ahmed et al. [15] reported the $\mathrm{IC}_{50}$ values of FSMEs against MCF-7 cell lines to be in the range of $2850-3140 \mu \mathrm{g} / \mathrm{mL}$. Meanwhile, the $\mathrm{IC}_{50}$ values determined by [15] were in the range of $1400-5605 \mu \mathrm{g} / \mathrm{mL}$, as similarly observed in the current study. However, the processing techniques of fenugreek seeds have been shown to affect the nutritional/chemical profile and antioxidant activity of fenugreek extracts [17].

The MTT assay in the current study showed that the first and third FPMEs had $\mathrm{IC}_{50}$ values of 812 and $526 \mu \mathrm{g} / \mathrm{mL}$, respectively, and were significantly more potent than the first and third FSMEs, which had $\mathrm{IC}_{50}$ values of 5605 and $1400 \mu \mathrm{g} / \mathrm{mL}$, respectively. These findings present new data to indicate that fenugreek sprouts have higher concentrations of cytotoxic compounds. In these extracts, the compounds detected included isoflavones, assigned as daidzein and formononetin, and were mainly present in the sprouts, which exhibited higher $\mathrm{IC}_{50}$ values of $152.2 \mu \mathrm{M}$ and $50.13 \mu \mathrm{M}$, respectively. These phytochemicals may have contributed to the observed cytotoxicity. This was consistent with earlier findings reporting that formononetin, a phytoestrogen, induced apoptotic cell death in diverse types of human cancers [18]. Moreover, soybean isoflavone (daidzein) has been shown to be cytotoxic to cultures of MCF-7 and MDA-MB-231 breast cancer cells [19]. Furthermore, we also report the detection of compounds assigned as steroidal saponins in the sprout extracts and emphasise that these and other detected compound classes in the fenugreek 
extracts may also have contributed to the observed cytotoxic effects in the current study. The findings from this study, therefore, underpin future research to elucidate which other chemical constituents of fenugreek sprouts mediate potential anti-cancer effects.

The anti-cancer activity of the fenugreek extracts was also evaluated via the degree of induced mtDNA damage. Mitochondrial dysfunction underlies the pathogenesis of a variety of disorders including cancer $[20,21]$. The survival of cancer cells is directly related to mtDNA half-life; therefore, an effective anti-cancer bioactive compound can significantly promote mtDNA damage (i.e., shorten its half-life). In the current study, the metastatic MCF-7 cells treated with fenugreek seed extracts exhibited significantly increased mtDNA damage (determined by the relative levels), which resulted in the suppression of cell proliferation, and hence suppressed the metastatic potential of the cells.

While there have been numerous published studies on the chemistry and bioactivities of fenugreek seeds [21-25], fenugreek sprouts and constituents, and their effects to mediate changes in cell viability and cell proliferation in MCF-7 cells, have not been assessed previously, which we present here for the first time. In conclusion, this study revealed that chemically profiled fenugreek seed and sprout extracts show anti-cancer effects in vitro, and provides the first evidence for the untapped potential of fenugreek sprouts for their role against certain forms of cancer.

Supplementary Materials: The following supplementary materials can be downloaded at: https: / / www.mdpi.com/article/10.3390/nu14040784/s1, Table S1: Detected compounds assigned from LC-MS analysis of the Trigonella foenum-graecum extracts.

Author Contributions: K.K.K. performed the experiments and wrote the manuscript; M.-J.R.H., R.H. and I.W.F. performed the LC-MS studies, and edited the manuscript; P.A.S. co-supervised the work and co-edited the manuscript; G.O.L.-D. conceptualised and supervised the work and wrote and edited the manuscript. All authors have read and agreed to the published version of the manuscript.

Funding: This research received no external funding. Kholoud Khoja receives financial sponsorship from King Abdullah Scholarship Programme, Saudi Arabia.

Conflicts of Interest: The authors declare no conflict of interest.

\section{References}

1. Plants of the World Online (POWO). Plants of the World Online; Royal Botanic Gardens: Kew, UK, 2020.

2. Basu, T.K.; Srichamroen, A. Health Benefits of Fenugreek (Trigonella foenum-graecum leguminosse). In Bioactive Foods in Promoting Health; Watson, R.R., Preedy, V.R., Eds.; Academic Press: San Diego, CA, USA, 2010; pp. $425-435$.

3. Balasubramanian, S.; Roselin, P.; Singh, K.K.; Zachariah, J.; Saxena, S.N. Postharvest Processing and Benefits of Black Pepper, Coriander, Cinnamon, Fenugreek, and Turmeric Spices. Crit. Rev. Food Sci. Nutr. 2015, 56, 1585-1607. [CrossRef] [PubMed]

4. Khan, F.; Negi, K.; Kumar, T. Effect of sprouted fenugreek seeds on various diseases: A review. J. Diabetes Metab. Disord. Control 2018, 5, 119-125. [CrossRef]

5. Chauhan, G.; Sharma, M.; Varma, A.; Kharkwal, H. Phytochemical analysis and anti-inflammatory potential of Fenugreek. Med. Plants-Int. J. Phytomed. Relat. Ind. 2010, 2, 39. [CrossRef]

6. Król-Kogus, B.; Głód, D.; Krauze-baranowska, M. Qualitative and quantitative HPLC-ELSD-ESI-MS analysis of steroidal saponins in fenugreek seed. Acta Pharm. 2020, 70, 89-99.

7. Benayad, Z.; Gómez-Cordovés, C.; Es-Safi, N.E. Characterization of Flavonoid Glycosides from Fenugreek (Trigonella foenumgraecum) Crude Seeds by HPLC-DAD-ESI/MS Analysis. Int. J. Mol. Sci. 2014, 15, 20668-20685. [CrossRef]

8. Amin, A.; Alkaabi, A.; Al-Falasi, S.; Daoud, S.A. Chemopreventive activities of Trigonella foenum graecum (Fenugreek) against breast cancer. Cell Biol. Int. 2005, 29, 687-694. [CrossRef]

9. Chand, P.; Singh, K.; Singh, B.N.; Naidu, A. Contribution of fenugreek (Trigonella foenum graecum L.) seeds towards the nutritional characterization. J. Med. Plant Res. 2013, 7, 3052-3058.

10. Schymanski, E.; Jeon, J.; Gulde, R.; Fenner, K.; Ruff, M.; Singer, H.; Hollender, J. Identifying Small Molecules Via High Resolution Mass Spectrometry: Communicating Confidence. Environ. Sci. Technol. 2014, 48, 2097-2098. [CrossRef]

11. Malik, A.N.; Czajka, A.; Cunningham, P. Accurate quantification of mouse mitochondrial DNA without co-amplification of nuclear mitochondrial insertion sequences. Mitochondrion 2016, 29, 59-64. [CrossRef]

12. Benayad, Z.; Gómez-Cordovés, C.; Es-Safi, N.E. Identification and quantification of flavonoid glycosides from fenugreek (Trigonella foenum-graecum) germinated seeds by LC-DAD-ESI/MS analysis. J. Food Compos. Anal. 2014, 35, 21-29. [CrossRef] 
13. Derzsi, M.; Grochala, W. Comment on "Pressure-induced structural and valence transition in AgO" by C. Hou, J. Botana, X. Zhang, X. Wang and M. Miao, Phys. Chem. Chem. Phys., 2016, 18, 15322. Phys. Chem. Chem. Phys. 2016, 18, 31973-31974. [CrossRef] [PubMed]

14. Rayyan, S.; Fossen, T.; Øyvind, A.M. Flavone C-Glycosides from Seeds of Fenugreek, Trigonella foenum-graecum L. J. Agric. Food Chem. 2010, 58, 7211-7217. [CrossRef] [PubMed]

15. Ahmed, S.I.; Hayat, M.Q.; Zahid, S.; Tahir, M.; Mansoor, Q.; Ismail, M.; Keck, K.; Bates, R. Isolation and identification of flavonoids from anticancer and neuroprotective extracts of Trigonella foenum graecum. Trop. J. Pharm. Res. 2017, 16, 1391. [CrossRef]

16. Sebastian, K.; Thampan, R.V. Differential effects of soybean and fenugreek extracts on the growth of MCF-7 cells. Chem. Biol. Interact. 2007, 170, 135-143. [CrossRef]

17. Pandey, H.; Awasthi, P. Effect of processing techniques on nutritional composition and antioxidant activity of fenugreek (Trigonella foenum-graecum) seed flour. J. Food Sci. Technol. 2015, 52, 1054-1060. [CrossRef]

18. Oh, J.; Kim, T.; Park, J.; Lim, H.; Cho, I.; You, J.; Lee, G.; Seo, Y.; Kim, D.K.; Kim, C.S.; et al. Formononetin induces apoptotic cell death through the suppression of mitogen-activated protein kinase and nuclear factor- $\mathrm{kB}$ phosphorylation in FaDu human head and neck squamous cell carcinoma cells. Oncol. Rep. 2019, 43, 700-710. [CrossRef]

19. Uifălean, A.; Schneider, S.; Gierok, P.; Ionescu, C.; Iuga, C.A.; Lalk, M. The Impact of Soy Isoflavones on MCF-7 and MDA-MB-231 Breast Cancer Cells Using a Global Metabolomic Approach. Int. J. Mol. Sci. 2016, 17, 1443. [CrossRef]

20. Holt, A.G.; Davies, A.M. The significance of mitochondrial DNA half-life to the lifespan of post-mitotic cells. bioRxiv 2020. [CrossRef]

21. Astley, S.; Elliott, R.; Archer, D.; Southon, S. DNA Damage and Repair: Relative Responses to Antioxidant Nutrients in the Diet. In Dietary Anticarcinogens and Antimutagens; Johnson, I.T., Fenwick, G.R., Eds.; Woodhead Publishing: Cambridge, UK, 2000; pp. 138-142.

22. Vígh, S.; Zsvér-Vadas, Z.; Pribac, C.; Mos, L.; Cziáky, Z.; Czapár, M.; Mihali, C.V.; Turcuş, V.; Remenyik, J.; Máthé, E. Fenugreek (Trigonella foenum-graecum L.) extracts are inducing dose-dependent hormetic response and cytotoxic effects in case of human breast cancer cell lines. J. Studia Univ. "Vasile Goldis" Arad Ser. Stiintele Vietii 2016, 26, 435.

23. Anju, V.S.; Sreeja, S. In vitro estrogenic activities of fenugreek Trigonella foenum-graecum seeds. Indian J. Med. Res. 2010, 131, 814-819.

24. Al-Oqail, M.M.; Farshori, N.N.; Al-Sheddi, E.S.; Musarrat, J.; Al-Khedhairy, A.A.; Siddiqui, M.A. In vitro cytotoxic activity of seed oil of fenugreek against various cancer cell lines. Asian Pac. J. Cancer Prev. 2013, 14, 1829-1832. [CrossRef] [PubMed]

25. Agustini, K.; Sumaryono, W.; Widyanto, R.M. Activity of Trigonella foenum-graecum on Some Cell Lines. Indones. J. Cancer Chemoprev. 2011, 2, 234-241. [CrossRef] 